\title{
Comparative Evaluation of Cariogenic and Erosive Potential of Commonly Prescribed Pediatric Liquid Medicaments: An in vitro Study
}

\author{
${ }^{1}$ Meenakshi Nankar, ${ }^{2}$ Hrishikesh Walimbe, ${ }^{3}$ Mohammed Nadeem Ahmed Bijle, ${ }^{4}$ Ujwal Kontham, ${ }^{5}$ Ananth Kamath \\ ${ }^{6}$ Sneha Muchandi
}

\begin{abstract}
Introduction: Liquid oral medicines being the most accepted form of medication in children are frequently prescribed. The harmful effects of these liquid medicaments on a child's dental health are not known to many. The present study aimed to evaluate and compare the cariogenic and erosive potential of 5 most commonly prescribed pediatric liquid medicaments (PLM) in Pimpri Chinchwad and Pune city, Pune district.
\end{abstract}

Materials and methods: Most commonly prescribed PLM in Pune district were selected as opined by 50 pediatricians. The selected medicaments were Syr. Augmentin ${ }^{\circledR}$ Duo, Syr. Valparin $^{\circledR}$, Syr. Combiflam ${ }^{\circledR}$, Syr. Visyneral and Syr. Orofer ${ }^{\circledR}$. An estimation of $\mathrm{pH}$, percentage of sucrose concentration and calcium dissolving capacity of these preparations was carried out. The results as obtained were subjected to statistical analysis using SPSS v 17.0 for windows. The statistical test as undertaken was Pearson's correlation coefficient( $r$ ).

Results: Sucrose was seen to be present in Syr. Combiflam ${ }^{\circledR}$ $(35.75 \% \pm 0.25 \%)$ and Syr. Visyneral $(18.48 \% \pm 0.43 \%)$. Acidic $\mathrm{pH}$ was observed for Syr. Visyneral (mean pH $3.63 \pm 0.04)$, Syr. Combiflam $^{\circledR}$ (mean pH $5.03 \pm 0.02$ ) and Syr. Augmentin ${ }^{\circledR}$ (mean $\mathrm{pH} 6.22 \pm 0.02$ ). Highest calcium dissolution was seen with Syr. Combiflam ${ }^{\circledR}(295.86 \mu \mathrm{g} / \mathrm{ml})$ and the least with Syr. Orofer ${ }^{\circledR}$ $(25.51 \mu \mathrm{g} / \mathrm{ml})$. No statistical significant correlation was observed with calcium dissolution potential of PLM in comparison with their respective $\mathrm{pH}$.

Conclusion: Syr. Combiflam ${ }^{\circledR}$ can be regarded as the highest cariogenic and erosive potential medicament among the compared and tested PLM.

Clinical significance: Considering syrups with high cariogenic and erosive potential should always follow with proper oral hygiene practices or search for an alternative drugs void of such detrimental effects.

Keywords: Cariogenic agents, Hydrogen-ion concentration, Pediatric liquid medicaments, $\mathrm{pH}$, Tooth erosion.

\footnotetext{
${ }^{1,6}$ Postgraduate Student, ${ }^{2}$ Reader, ${ }^{3,5}$ Lecturer, ${ }^{4}$ Professor

${ }^{1-6}$ Department of Pedodontics and Preventive Dentistry Dr DY Patil Vidyapeeth, Dr DY Patil Dental College and Hospital Pimpri, Pune, Maharashtra, India
}

Corresponding Author: Mohammed Nadeem Ahmed Bijle Lecturer, Department of Pedodontics and Preventive Dentistry, DY Patil Vidyapeeth, Dr DY Patil Dental College and Hospital, Pimpri Pune, Maharashtra, India, e-mail: info@drnadeembijle.com
How to cite this article: Nankar M, Walimbe $\mathrm{H}$, Bijle MNA, Kontham U, Kamath A, Muchandi S. Comparative Evaluation of Cariogenic and Erosive Potential of Commonly Prescribed Pediatric Liquid Medicaments: An in vitro Study. J Contemp Dent Pract 2014;15(1):20-25.

Source of support: Nil

Conflict of interest: None

\section{INTRODUCTION}

Liquid medicated forms designated as syrups or drinks are the most prescribed configuration in children. These medicaments are recommended by physicians or pediatricians for short intervals in common diseases like cough and cold and also over prolonged periods with daily consumption in chronic diseases like asthma, epilepsy, nutritional deficiency, etc. The palatability of pediatric liquid medicaments (PLMs) is renowned in children as compared to its commonly used counter physical state - tablet. ${ }^{1}$ The recognition is esp-ecially due in sweetened preparations of the former. Sucrose is the commonly adjoined sweetener to such medicated formulations since it is available as a low cost and easily processed substance. ${ }^{2}$ There is an overwhelming evidence incriminating dietary sugar-chiefly sucrose which is considered an arch criminal, as a major etiological factor for dental caries. ${ }^{3}$ Thus, there seems to be a possibility of dental caries with the use of such sweetened PLM, which thereby acts as an additional risk factor in caries process.

Pediatric liquid medicaments not only contain sweetening agents but also acids. The acids are added as buffering agents to maintain chemical stability, control tonicity or to ensure physiological compatibility. They also improve flavor to consequently enhance the patient compliance. ${ }^{4}$ Apart from the benefits derived; there are associated detrimental effects of such acids termed dental erosion. Hence, due to the added acid contents, PLM can be related as one of the major causes for dental erosion as well. ${ }^{5-7}$

Studies have shown that routine use of PLM can reduce enamel hardness of primary teeth, ${ }^{8}$ influence enamel roughness, ${ }^{9}$ cause morphological enamel alteration, ${ }^{10,11}$ induce degradation of composite materials, cause dentinal hypersensitivity ${ }^{12}$ and also lead to increase prevalence 
of dental caries. ${ }^{13}$ Thus, it appears that the ill-effects of such preparations have undergone a thorough qualitative evaluation to check their erosive potential. Apart, evidence for quantitative analysis of dental caries is also available in the literature. ${ }^{13,14}$ However, there are only few studies ${ }^{15,16}$ which have quantified the erosive potential of PLM in primary teeth. Along with, dental professionals are unaware about the sucrose content of commonly prescribed PLM in the vicinity of practice; which if known can be noted for a harmless alternative therapeutic agent thus reducing the risk of dental caries.

Hence, the present study was carried out to evaluate the cariogenic and erosive potential of the most commonly prescribed PLM by estimation of their endogenous $\mathrm{pH}$, sucrose concentration and quantification of their calcium dissolving capacity.

\section{MATERIALS AND METHODS}

Five most commonly prescribed PLM were selected for the study by consulting 50 pediatricians in Pimpri Chinchwad and Pune city, Pune district area (Table 1 and Fig. 1).

\section{Quantitative Endogenous Sucrose Estimation}

Lane-Eynon volumetric copper reduction method (AOAC method 968.281) was used for estimation of endogenous sucrose concentration (Fig. 2). The method measures the sucrose concentration using percentage of glucose concentration as a guidance considering the fact that sucrose is a disaccharide of glucose and fructose. The glucose standards and medicine samples were weighed (2-5 gm). The weighed PLM was made to $100 \mathrm{ml}$ using deionized water. This solution was transferred to a burette and used to titrate the Fehling's solution under shaking and boiling conditions. The amount of solution used (ml) to titrate the Fehling's solution was recorded to estimate the percentage (wt/wt) of free glucose as in equation below (Glucose $\mathrm{a}_{\mathrm{a}}$ ):

$$
\begin{aligned}
& \text { Glucose }(\%)=\frac{3.905}{2} \times \frac{\mathrm{V}^{-1.0251}}{\mathrm{P}} \times 100 \\
& \mathrm{~V}-\text { volume of sample solution }(\mathrm{ml}) \\
& \mathrm{P}-\text { amount of sample }(\mathrm{gm})
\end{aligned}
$$

Medicine samples were prepared again to $100 \mathrm{ml}$ using deionized water, which were acidified with $1 \mathrm{ml}$ of $\mathrm{HCl}(32 \%)$ and heated in water bath $\left(100^{\circ} \mathrm{C} \pm 2^{\circ} \mathrm{C}\right)$ for 40 minutes to accelerate the hydrolysis of sucrose. After cooling, the solutions were neutralized with sodium hydroxide ( $40 \% \mathrm{wt} / \mathrm{volume}$ ). Fehling's solution was titrated by the neutralized PLM sample as per the aforementioned procedure to determine glucose concentration (Glucose $e_{b}$ ). Sucrose concentration was then estimated by difference between glucose concentration of the sample solution after

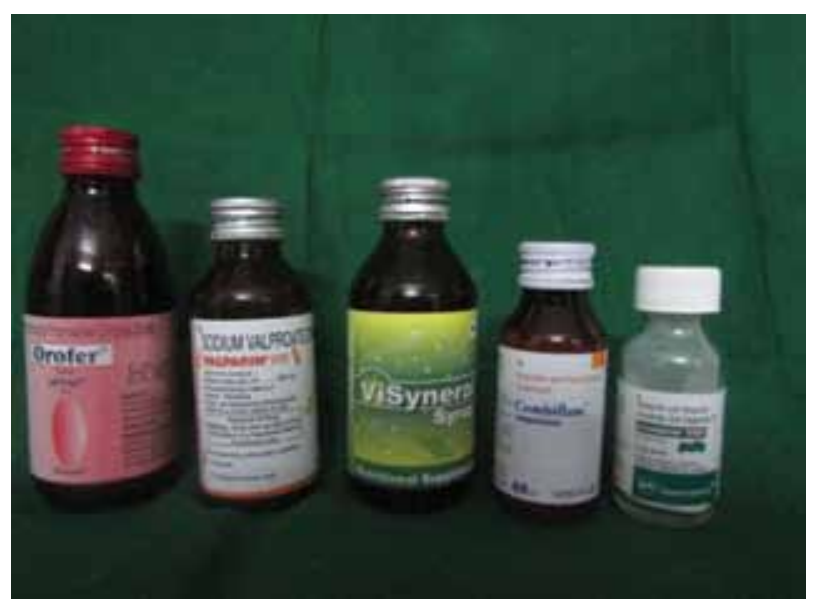

Fig. 1: Commonly used PLM in Pimpri-Chinchwad and Pune city-Pune district area

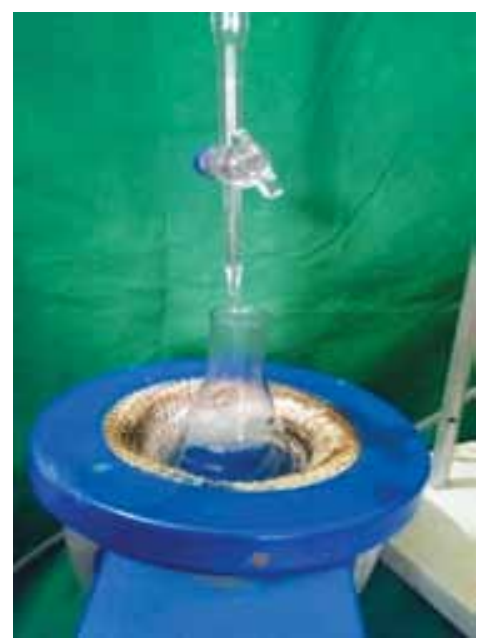

Fig. 2: Lane-Eynon test for sucrose estimation-titration of the Fehling's solution by the medicine sample in burette

Table 1: Commonly used PLM by pediatricians in Pimpri-Chinchwad and Pune city-Pune district area

\begin{tabular}{llll}
\hline Pediatric liquid medicine & Generic name & Trade name & Pharmacological company \\
\hline Analgesic, antipyretic & Ibuprofen and Paracetamol & Syrup Combiflam ${ }^{\circledR}$ & Sanofi India Ltd., Gujarat, India \\
Antibiotic & $\begin{array}{l}\text { Amoxicillin and } \\
\text { Potassium clavulanate }\end{array}$ & Syrup Augmentin ${ }^{\circledR}$ Duo & $\begin{array}{l}\text { GlaxoSmitheKline Pharmaceutical } \\
\text { Ltd., Mumbai, India }\end{array}$ \\
Nutritional supplement & Multivitamin & Syrup Visyneral & $\begin{array}{l}\text { Crest Healthcare P. Ltd., Himachal } \\
\text { Pradesh, India }\end{array}$ \\
Iron supplement & Iron hydroxide and & Syrup Orofer ${ }^{\circledR}$ & Emcure Pharmaceutical Ltd., Jammu, \\
Antiepileptic & Solymaltose complex & India & Sanofi-Synthelabo Ltd., Gujarat, India \\
\hline
\end{tabular}


acid inversion (Glucose $\mathrm{b}_{\mathrm{b}}$ ) and the concentration of glucose determined in comparison with control (Glucose $\mathrm{a}_{\mathrm{a}}$ ), according to the following equation:

Sucrose $(\%)=\left(\right.$ Glucose $\left._{\mathrm{b}}\right)-\left(\right.$ Glucose $\left._{\mathrm{a}}\right)$

All the PLMs were analyzed in triplicate.

\section{Endogenous pH Estimation}

The endogenous $\mathrm{pH}$ was measured using a digital $\mathrm{pH}$ meter (Fig. 3) at $10 \%$ dilution. The $\mathrm{pH}$ meter was calibrated by using buffer solution of $\mathrm{pH} 7$ and 4 (by buffer standard capsule). All the readings were taken in triplicate.

\section{Quantification of Endogenous Erosive Potential}

Sixteen caries and restoration free, freshly exfoliated or extracted primary teeth were utilized to produce 1 to $1.5 \mathrm{gm}$ enamel powder. Each tooth was sliced mesiodistally using a diamond disk. The internal dentin support was removed using round diamond bur. Remaining enamel shells were grounded to a fine powder using a mortar and pestle. The powder was sieved through a standard no. 85 sieve to standardize the particle size (Fig. 4).

A $50 \mathrm{mg}$ of enamel powder was then added to $1 \mathrm{ml}$ of individual PLM. The mixtures were maintained for three time intervals viz 1 minute, 10 minutes and 8 hours. The samples were then prepared for estimation of calcium using atomic absorption spectrometer (Fig. 5). Inherent calcium content was also determined for each PLM.

After keeping the mixtures for the said time interval, the undissolved enamel powder was removed by centrifugation for 10 minutes at $5000 \mathrm{rpm} .0 .5 \mathrm{ml}$ of the supernatant was taken and weighed in crucible. This crucible containing supernatant was placed in a hot air oven at $100^{\circ} \mathrm{C}$ for 2 to 3 hours, then ashed in furnace at $650^{\circ} \mathrm{C}$ for 15 to 16 hours. Ash was then dissolved in $0.2 \mathrm{ml} \mathrm{HCl}$. Final volume was made up to $100 \mathrm{ml}$ with distilled water. The sample was then ready for atomic absorption spectrometer injection. Standard solutions of $0.5,5$ and $15 \mathrm{ppm}$ were used for calibration (Shimadzu. Model no. AA7000, Maryland, North America) (see Fig. 5).

The results as obtained were subjected to statistical analysis using SPSS v 17.0 for windows (Chicago Inc, USA). The statistical test as undertaken was Pearson's correlation coefficient (r).

\section{RESULTS}

Sucrose was seen to be present in Syr. Combiflam ${ }^{\circledR}$ in the mean concentration of $35.75 \% \pm 0.25 \%$ and in Syr. Visyneral in the mean concentration of $18.48 \% \pm 0.43 \%$, whereas Syr. Augmentin $^{\circledR}$ Duo, Syr. Valparin ${ }^{\circledR}$ and Syr. Orofer ${ }^{\circledR}$ were devoid of sucrose content (Table 2).

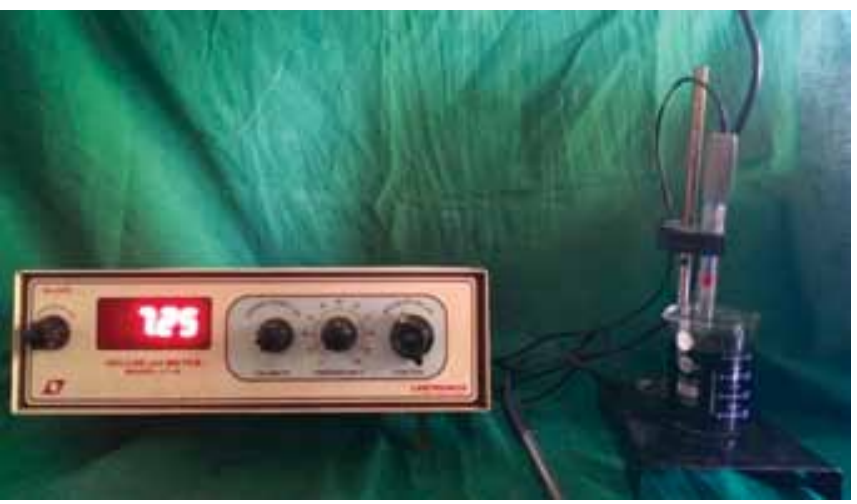

Fig. 3: Portable standard digital $\mathrm{pH}$ meter (Deluxe Labtronics LT 10, Haryana, India)

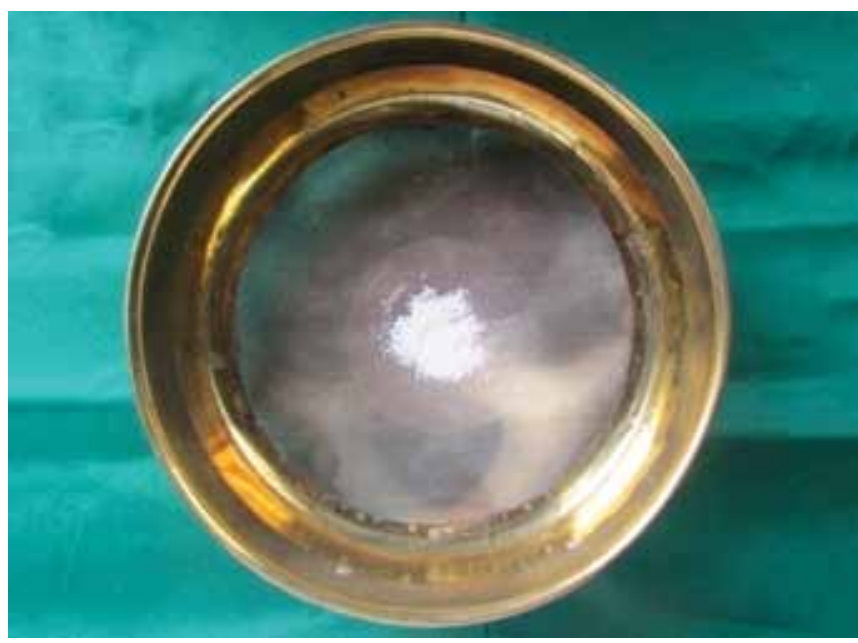

Fig. 4: Sieving the enamel powder through standard no. 85 mesh

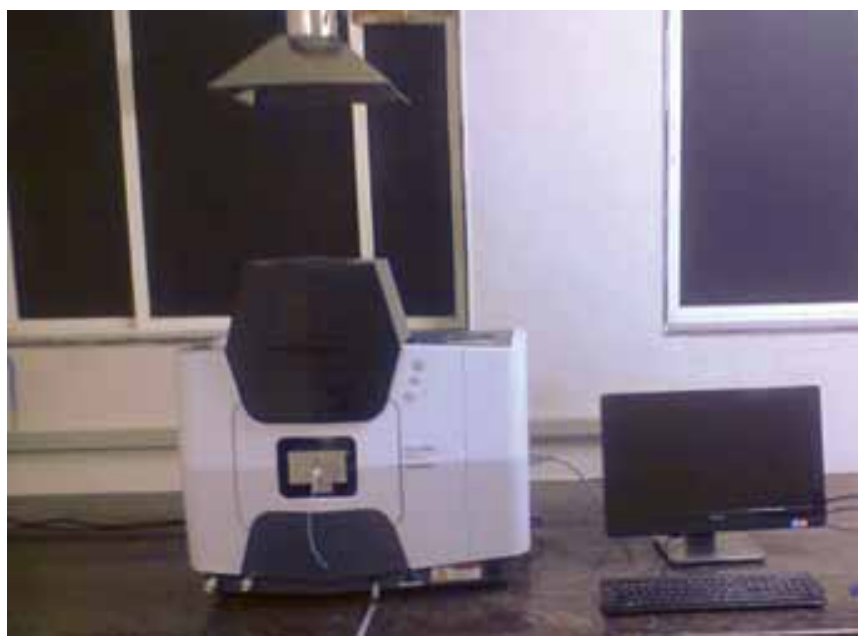

Fig. 5: Atomic absorption spectrometer (Shimadzu Model no. AA 7000, Maryland, North America)

Acidic $\mathrm{pH}$ was observed for Syr. Visyneral (mean $\mathrm{pH}$ $3.63 \pm 0.04$ ), Syr. Combiflam ${ }^{\circledR}$ (mean pH $5.03 \pm 0.02$ ) and Syr. Augmentin ${ }^{\circledR}$ (mean pH 6.22 \pm 0.02 ); whereas Syr. Val$\operatorname{parin}^{\circledR}$ (mean pH 7.36 \pm 0.01 ) and Syr. Orofer ${ }^{\circledR}($ mean pH $7.24 \pm 0.03$ ) depicted basic $\mathrm{pH}$ (Table 3).

Calcium was found to be present in all the pediatric liquid medicaments except Syr. Orofer ${ }^{\circledR}$. Maximum calcium was 
Table 2: Sucrose concentration of the PLM

\begin{tabular}{|c|c|c|c|c|}
\hline Sr. no. & Name of PLM & Sugar content & Mean & $S D$ \\
\hline 1. & Syr. Combiflam ${ }^{\circledR}$ & $\begin{array}{l}35.50 \% \\
35.75 \% \\
36.00 \%\end{array}$ & $35.75 \%$ & $\pm 0.25 \%$ \\
\hline 2. & Syr. Augmentin Duo ${ }^{\circledR}$ & Nil & - & - \\
\hline 3. & Syr. Visyneral & $\begin{array}{l}18.40 \% \\
18.95 \% \\
18.10 \%\end{array}$ & $18.48 \%$ & $\pm 0.43 \%$ \\
\hline 4. & Syr. Orofer ${ }^{\circledR}$ & Nil & - & - \\
\hline 5. & Syr. Valparin ${ }^{\circledR}$ & $\mathrm{Nil}$ & - & - \\
\hline
\end{tabular}

Table 3: $\mathrm{pH}$ of the commonly used PLM

\begin{tabular}{|c|c|c|c|c|}
\hline Sr. no. & Name of medicine & $p H(10 \%)$ & Mean $p H$ & $S D$ \\
\hline 1. & Syr. Combiflam ${ }^{\circledR}$ & $\begin{array}{l}5.01 \\
5.04 \\
5.03\end{array}$ & 5.03 & \pm 0.02 \\
\hline 2. & Syr. Augmentin ${ }^{\circledR}$ Duo & $\begin{array}{l}6.20 \\
6.24 \\
6.22\end{array}$ & 6.22 & \pm 0.02 \\
\hline 3. & Syr. Visyneral & $\begin{array}{l}3.60 \\
3.68 \\
3.62\end{array}$ & 3.63 & \pm 0.04 \\
\hline 4. & Syr. Orofer ${ }^{\circledR}$ & $\begin{array}{l}7.25 \\
7.21 \\
7.26\end{array}$ & 7.24 & \pm 0.03 \\
\hline 5. & Syr. Valparin ${ }^{\circledR}$ & $\begin{array}{l}7.35 \\
7.37 \\
7.35\end{array}$ & 7.36 & \pm 0.01 \\
\hline
\end{tabular}

Table 4: Calcium dissolution potential of the PLM

\begin{tabular}{llllllll}
\hline Name of medicine & $\begin{array}{l}\text { Calcium } \\
\text { present in } \\
\text { syrup }(\mu \mathrm{g})\end{array}$ & $\begin{array}{l}\text { Calcium } \\
\text { present in } \\
\text { syrup at } \\
1 \mathrm{~min}(\mu \mathrm{g})\end{array}$ & $\begin{array}{l}\text { Calcium } \\
\text { present in } \\
\text { syrup at 10 } \\
\text { mins }(\mu \mathrm{g})\end{array}$ & $\begin{array}{l}\text { Calcium } \\
\text { present in } \\
\text { syrup at } \\
8 \mathrm{hrs}(\mu \mathrm{g})\end{array}$ & $\begin{array}{l}\text { Calcium } \\
\text { dissolution from } \\
\text { syrup at 1 min } \\
(\mu \mathrm{g})\end{array}$ & $\begin{array}{l}\text { Calcium } \\
\text { dissolution from } \\
\text { syrup at 10 } \\
\text { mins }(\mu \mathrm{g})\end{array}$ & $\begin{array}{l}\text { Calcium } \\
\text { dissolution } \\
\text { from syrup } \\
\text { at } 8 \mathrm{hrs}(\mu \mathrm{g})\end{array}$ \\
\hline Syr. Combiflam $^{\circledR}$ & 32.67 & 48.78 & 62.53 & 328.53 & 16.11 & 29.86 & 295.86 \\
Syr. Augmentin $^{\circledR}$ Duo & 34.17 & 44.99 & 58.61 & 315.18 & 10.82 & 24.44 & 281.01 \\
Syr. Visyneral $^{\text {Syr. Orofer }}{ }^{\circledR}$ & 28.67 & 37.87 & 43.84 & 169.39 & 9.26 & 15.23 & 140.78 \\
Syr. Valparin $^{\circledR}$ & 0 & 10.64 & 12.42 & 25.51 & 10.64 & 12.42 & 25.51 \\
\hline
\end{tabular}

present in Syr. Augmentin ${ }^{\circledR}$ Duo $(34.17 \mu \mathrm{g} / \mathrm{ml})$ and least in Syr. Valparin $^{\circledR}(23.34 \mu \mathrm{g} / \mathrm{ml})$ (Table 4).

Calcium dissolution was seen at all three time intervals for all the PLM. As the time of immersion in PLM increased, the amount of calcium dissolution also increased. Highest calcium dissolution was seen with Syr. Combiflam ${ }^{\circledR}$ (295.86 $\mu \mathrm{g} / \mathrm{ml})$ and the least with Syr. Orofer ${ }^{\circledR}(25.51 \mu \mathrm{g} / \mathrm{ml})$.

Calcium dissolution potential of PLM was compared with their respective $\mathrm{pH}$ using Pearson's correlation coefficient (r). There was no statistical significant correlation observed (Table 5).

\section{DISCUSSION}

The frequent use of liquid oral medicines put children at risk of dental caries and erosion, as demonstrated by various clinical studies. ${ }^{5,13,14}$ Maguire, Rugg-Gunn and Butler, ${ }^{13}$ in a survey conducted, found that the dental health of children taking long-term liquid medication to be worse than their siblings in relation to anterior teeth decay in deciduous dentition which can be substantiated with the results of this study. In another study conducted by Pradhan D et al ${ }^{17}$ showed a fall in mean salivary $\mathrm{pH}$ below critical $\mathrm{pH}$ for up to 6 minutes after a $25 \%$ sucrose rinse, making children consuming sucrose containing PLM prone to dental caries.

Syr. Combiflam ${ }^{\circledR}$, a commonly used analgesic and antipyretic, showed the highest concentration of sucrose $(35.75 \%)$ and Syr. Visyneral, a nutritional supplement showed $18.48 \%$ of sucrose. These findings are in accordance with findings of Lima et $\mathrm{al}^{18}$ (2000), Kenny and Somaya ${ }^{19}$ (1989) and Santos Pinto et $\mathrm{al}^{20}$ (2000). Lima et $\mathrm{al}^{18}$ recorded 
Table 5: Correlation between $\mathrm{pH}$ and calcium dissolving capacity

\begin{tabular}{lllll}
\hline Name of medicine & pH of medicine & \multicolumn{3}{c}{ Enamel calcium dissolution $(\mu \mathrm{g})$} \\
\cline { 3 - 5 } & & $1 \mathrm{~min}$ & 10 mins & 8 hrs \\
\hline Syr. Combiflam $^{\circledR}$ & 5.03 & 16.11 & 29.86 & 295.86 \\
Syr. Augmentin $^{\circledR}$ Duo & 6.22 & 10.82 & 24.44 & 281.01 \\
Syr. Visyneral $^{\text {Syr. Orofer }}{ }^{\circledR}$ & 3.63 & 9.26 & 15.23 & 140.78 \\
Syr. Valparin $^{\circledR}$ & 7.24 & 10.64 & 12.42 & 25.51 \\
Correlation $^{(r)}$ & 7.36 & 3.42 & 6.57 & 100.27 \\
p-Value & - & -0.42 & -0.44 & -0.41 \\
\hline p-value measurement using Pearson's correlation coefficient $(r)$ & & $>0.05$ \\
\end{tabular}

that $58.3 \%$ of the medicines studied contained sucrose as a sweetening agetnt. In the current study, only $2(40 \%)$ of 5 PLM tested contained sucrose. Such scores is possible due to less number of medicaments included in the study as pediatricians of the district relate only these preparation to be the most commonly prescribed in their routine consultancies.

An acidic $\mathrm{pH}$ was estimated for three $(60 \%)$ out of five PLMs selected for the study. Syr. Visyneral showed an exceedingly low $\mathrm{pH}$ of 3.63, which is in confirmation with a study conducted by Subramaniam ${ }^{21}$ in 2012. Syr. Combiflam $^{\circledR}$, a frequently used analgesic and antipyretic, had a $\mathrm{pH}$ of 5.03 which appears to be lower than critical $\mathrm{pH}$ thus rendering these as potential for caries process.

As an objective of the present study, the presence or absence of baseline calcium was noted and calcium concentration was determined for the selected PLM since ions like calcium, phosphate and fluoride have a protective effect against erosion. Even though, all the PLMs demonstrated calcium dissolution with the maximum amount of dissolution at 8 hours interval followed by 10 minutes and 1 minute interval. Similar results were obtained in a study conducted by Hunter et $\mathrm{al}^{22}$ (2000) which showed that increase in exposure time to acidic products worsened the occurrence of erosion. Girish Babu (2008) $)^{15}$ also quantified the calcium dissolution from primary enamel at three time intervals ( 1 minute, 10 minutes and 8 hours) and found similar results. Calcium dissolution was evident at alkaline $\mathrm{pH}$ and also at acidic $\mathrm{pH}$ which can be due to chelation. The citrate ions acting as chelating agents present in these medicaments would have been the cause for decalcification of primary enamel surface.

The present study did not measure the viscosity and titrable acidity of the selected PLM, which are also measures of cariogenic and erosive potential. Limitation of in vitro study also needs consideration while applying the results in clinical scenario. It is hereby suggested that general practitioners, pediatricians and dentists should be informed about the underestimated side effect of these prescriptions and precautions to be taken therewith. Each prescription of sugared medicine should include oral hygiene advice and preference should be given to those medicines sweetened with noncariogenic sugars.

\section{CONCLUSION}

Thus, it can be concluded that:

1. Syr. Combiflam ${ }^{\circledR}$ and Syr. Visyneral contain sucrose as a component.

2. Syr. Visyneral and Syr. Combiflam ${ }^{\circledR}$ were estimated with acidic $\mathrm{pH}$ below critical $\mathrm{pH}$.

3. Maximum calcium dissolution was seen with Syr. Combiflam $^{\circledR}$ in comparison with all other PLM which demonstrated dissolution to an extent.

Hence, Syr. Combiflam ${ }^{\circledR}$ can be regarded with the highest cariogenic and erosive potential among the compared and tested PLM.

\section{CLINICAL SIGNIFICANCE}

Pediatric dental practitioners while considering syrups with high cariogenic and erosive potential should always follow the patient with proper oral hygiene instructions and practices or search for an alternative drugs void of such detrimental effects.

\section{REFERENCES}

1. Joshi N. Routes for drug administration in children. In: Joshi N, editor. Guidelines for Pediatric Drug Prescribing for Family Physicians. New Delhi:Popular Prakashan; 2005. pp. 5.

2. Bigeard L. The role of medication and sugars in pediatric dental patients. Dent Clin North Am 2000;44:443-456.

3. Paes Leme A, Koo H, Bellato C, Bedi G, Curry J. The role of sucrose in cariogenic dental biofilm formation - new insight. J Dent Res 2006;85:878-887.

4. Maguire A, Baqir W, Nunn J. Are sugar free medicines more erosive than sugar containing medicines? An in vitro study of pediatric medicines with prolonged oral clearance used regularly and long term by children. Int J Paediatr Dent 2007;17:231-238.

5. Taji S, Seow W. A literature review of dental erosion in children. Aust Dent J 2010;55:358-367. 
6. Gandara B, Truelove E. Diagnosis and management of dental erosion. J Contemp Dent Pract 1999;1(1):1-17.

7. Bavbek A, Dogan O, Yilmaz T, Dogan A. The role of saliva in dental erosion and a prosthetic approach to treatment: a case report. J Contemp Dent Pract 2009;10(3):74-80.

8. Costa C, Almeida I, Costa Filho L. Erosive effect of an antihistamine-containing syrup on primary enamel and its reduction by fluoride dentifrice. Int J Paediatr Dent 2006;16:174-180.

9. Pierro V, Maia L, Silva E. Effect of pediatric syrups on roughness and erosion of enamel. Honolulu: IADR 82nd General Session and Exhibition; 2004.

10. Babu KL, Rai K, Hegde AM. Pediatric liquid medicaments- do they erode the teeth surface? An in vitro study: Part I. J Clin Pediatr Dent 2008;32:189-194.

11. Costa C, Almeida I, Costa Filho L, Oshima H. Morphology evaluation of primary enamel exposed to antihistamine and fluoride dentifrice — an in vitro study. Gen Dent 2006;54(1): 21-27.

12. Bamise C, Olusile A, Oginni A. An analysis of the etiological and predisposing factors related to dentinal hypersensitivity. $\mathrm{J}$ Contemp Dent Pract 2008;9(5):52-59.

13. Maguire A, Rugg-Gunn A, Butler T. Dental health of children taking antimicrobial and nonantimicrobial liquid oral medication long term. Caries Res 1996;30(1):16-21.
14. Sahgal J, Sood P, Raju O. A comparison of oral hygiene status and dental caries in children on long-term liquid oral medications to those not administered with such medications. J Indian Soc Pedod Prev Dent 2002;20(4):144-151.

15. Babu K, Rai K, Hegde A. pH of medicated syrups - does it really matter? - an in vitro study. Part II. JClin Pediatr Dent 2008;33:137-142.

16. McClure F, Ruzicka S. The destructive effect of citrate vs lactate ions on rats molar tooth surfaces in vivo. J Dent Res 1946;25:1-12.

17. Pradhan D, Jain D, Gulati A, Kolhe S, Baad R, Rao B. Effect of the presence of dental plaque on oral sugar clearance and salivary pH: An in vivo study. J Contemp Dent Pract 2012;13(6):753-755.

18. Lima K, Almeida I, Senna E. Pediatric medication-Sweetener agents and pH. J Bras Odontoped Odonto Bebe 2000;3:457-463.

19. Kenny DJ, Somaya P. Sugar load of oral liquid medications on chronically ill children. J Can Dent Assoc 1989;55:43-46.

20. Santos-Pinto L, Uema AP, Galassi MA, Ciuff NJ. What do pregnant women know about oral health? J Bras Odontoped Odonto Bebe 2001;4:429-434.

21. Subramaniam P, Nandan N. Cariogenic potential of pediatric liquid medicaments - an in vitro study. J Clin Pediatr Dent 2012;36(4):357-362.

22. Hunter M, West N, Hughes J, Newcombe R, Addy M. Erosion of deciduous and permanent dental hard tissues in the oral environment. J Dent 2000;28:257-263. 